\title{
Financial Reform, Ownership and Performance in Banking Industry: The Case of Bangladesh
}

\author{
S. M. Sohrab Uddin \\ PhD Student, Graduate School of Asia Pacific Studies \\ Ritsumeikan Asia Pacific University, Japan \\ \& \\ Assistant Professor, Department of Finance and Banking, University of Chittagong, Bangladesh \\ E-mail: smsohrabcu@yahoo.com \\ Yasushi Suzuki \\ Professor, Graduate School of Management \\ Ritsumeikan Asia Pacific University, Japan \\ E-mail: szkya@apu.ac.jp
}

Received: December 17, 2010 Accepted: January 20, $2011 \quad$ doi:10.5539/ijbm.v6n7p28

\begin{abstract}
Bangladesh entered into the era of financial reform during the early 1980s. Most of the reforms initiated by the government have concentrated predominantly on the banking sector. Consequently, many changes relating to ownership, market concentration, regulatory measures and policies have taken place primarily to enhancing bank performance. In this regard, this study is undertaken to investigate the performance of commercial banks after the implementation of significant financial reform. Data Envelopment Analysis based frontier measures income and cost efficiency and traditional non-frontier measures non-performing loans and return on assets have been used for assessing bank performance. The findings indicate that income and cost efficiency of sample banks have increased by 37.84 percent and 15.28 percent respectively in 2008 compared to 2001. Similarly, non-performing loans and return on assets also report improvement in bank performance. The results generated by regression models indicate that foreign ownership has a statistically significant positive impact on bank performance. On the other hand, private ownership has favorable impact on income efficiency, return on assets, and non-performing loans, whereas negative impact on cost efficiency.
\end{abstract}

Keywords: Financial reform, Ownership, Bank performance, DEA, Bangladesh

\section{Introduction}

In recent times, financial system, which can be defined as the combination of financial markets, financial instruments, financial institutions, and arrangement; has experienced dramatic turnaround due to the adoption of financial reform policy by most of the countries of the world. The buzzword 'financial reform' was initiated in developed countries (Galagedera and Edirisuriya, 2005). The underlying facts behind the initiation were deregulation of the financial system, enhancement of the degree of competition, elimination of the imbalances in financial markets, and improvement of the performance of banks and other financial institutions within the financial system. Afterwards, many developing countries entered into the world of financial reform in response to either internal or external pressure; the internal pressure was emerged from serious macroeconomic problems and the external pressure was created by donor agencies like International Monetary Fund (IMF) and World Bank (Hossain and Chowdhury, 1996, p. 67). Under this changing scenario, regulatory authorities are highly interested in measuring the performance of banks in terms of profitability, cost efficiency, asset quality, management efficiency, etc. to have a clear picture about the impact of financial reform program on banks. Banks also show keen interest on this since the atmosphere has been electrifying by the emergence of financial reform, financial innovation, and automation (Claudia et al., 2004). In view of these, many studies have been undertaken to investigate the performance of banks in the light of financial reform. These analyses are really crucial since conclusions can be drawn which not only help the regulatory authority to further regulate or deregulate the financial sector but also to retain the financial structure harmless $(\mathrm{Wu}, 2005)$.

Financial reform has brought massive changes in the ownership structure of the banking industry. Before financial reforms, banks meant predominantly state-owned commercial banks that performed functions on the basis of the direction given by the state government. Their prime job was to patronize state-owned enterprises. 
But the atmosphere started to change when countries embraced the new regime of financial reform. With the help of financial reform low-performing state-owned banks were privatized, entry of foreign banks was relaxed, and promotion of domestic commercial banks was prioritized. All of these are expected to have significant positive influence on the performance of the banking sector.

Bangladesh also adopted financial reform program during 1980s and consequently, number of foreign and domestic private banks started to increase. Although both bank-based system and market-based system have been available for financial intermediation in Bangladesh, the majority of the fund transfer relative to gross domestic product (GDP) is done by banks. It was almost 74 percent in the year 2008 (Bangladesh Economic Review 2008, p. 261) and therefore it can be concluded that banks play first and foremost role in the economic development process of Bangladesh. Beck and Rahman (2006) support this argument by stating that other forms of the financial intermediation in Bangladesh are significantly less developed compared to the banking sector. But, the amount of researches conduced with reference to financial reform and bank performance is substantially insignificant and as such the outcome of the financial reform program is unattended and hence remains unclear. In this regard, the present study is conducted to measure the performance of commercial banks in Bangladesh after the implementation of financial reform by using reliable measures of bank performance. Additionally, it focuses on the ownership effect on bank performance and thereby gives some directions for the future development of the banking system.

This paper makes contributions in three different ways. Firstly, it will add new evidence on the existing literature in the context of a developing country like Bangladesh by addressing the performance of commercial banks after financial reform. Secondly, no research prior to this uses Data Envelopment Analysis (DEA) grounded bank performance measurement to address the impact of financial reform in Bangladesh and accordingly it will add new dimension in bank performance measurement. Finally, it will provide valuable directions for the development of the banking sector and for conducting future research.

The later part of the paper is organized as follows: section two gives a theoretical background of the previous researches conducted on bank performance after financial reform and the impact of ownership on bank performance, section three provides a brief overview of the banking sector of Bangladesh, section four elaborates the methodology of the study, section five concentrates on the analysis and findings, and section six provides the conclusion and directions for conducting further research.

\section{Literature Review}

\subsection{Financial Reform and Bank Performance}

The outcomes of the financial reform program are mixed (Strum and Williams, 2004). This is because some researchers have identified improved performance of banks after the adoption of financial reform and some others do not attain any evidence of improvements during post-reform period. The next few sections will focus on the experiences of different countries of the world relating to bank performance after financial reform

Financial reform reshapes both cost and income efficiency of the US banking sector. According to Bauer et al. (1993), Humphrey and Pulley (1997), and Berger et al. (2000) financial reform has a significant negative impact on cost efficiency given the fact that high degree of competition increases the procurement cost of banks which in turn reduces the bank spread. Similar finding is also noticed by Berger and Mester (2001). Chaffai (1997) mentions that Tunisian banks have become less efficient after the adoption of financial liberalization. Avkiran (2000) studies productivity of ten Australian banks during 1986-1995 with reference to financial reform and attributes the increase in productivity over the period to technological advancement rather than to technical efficiency. Sturm and Williams (2004) also report similar findings in Australia.

In contrast, Claudia et al. (2004) analyze cost efficiency of banks after financial reform using stochastic cost function in Italy and suggest that deregulation has a positive impact on banks to improve the cost efficiency of the entire banking sector. Maudos and Paster (2003), who examine the efficiency of Spanish banks relating to financial reform, opine that increased competition and reduction of market power guaranteed by financial reform have a positive impact on the efficiency of commercial banks. Isik and Hasan (2003) use Malmquist total factor productivity index for investigating the performance of Turkish commercial banks and find that financial reform has a positive influence on bank performance during the period 1980-1990. Leightner and Lovell (1998) investigate the productivity of Thai banks with reference to financial reform during the period 1989-1994 and notice an improvement in productivity, more specifically an average improvement of nearly 20 percent per annum from 1992 to 1994 (p. 126).

Ali et al. (2004) make a comparative analysis of the Indian and Pakistani banking sectors by employing DEA for measuring the efficiency in terms of resource utilization for credit expansion and income generation of all commercial banks in India and Pakistan and reflect an improvement in bank efficiency in both India and Pakistan, especially during the post-financial reform period. An improvement in bank performance with reference to financial reform is also reported by Chen (2001) and Shyu (1998) who investigate bank efficiency of Taiwanese banks after the implementation of financial liberalization (Note 1), Berg et al. (1992) who investigate the productivity growth of Norwegian commercial banks using Malamquist indices with relation to financial 
deregulation during 1980-1989, and Canhoto and Dermine (2003) who compare the efficiency of new and old banks in Portugal during the post liberalization period.

The reasons for the differences in bank performance with regard to financial reform can be explained by the statement made by Sturm and Williams (2004) and Berger and Humphrey (1997). They argue that that the nature of financial reform and the structure of the financial system previous to the implementation phase are the two influential factors deciding the result of financial reform in a country.

It is also important to mention that studies conducted in the same country are not always reflecting the similar result simply because of the differences in sample periods, sample sizes, and techniques of performance measurement. The findings of the researches conducted on Korean banks give an indication towards this statement. Gilbert and Wilson (1998) employ Malmquist index to measure the changes in productivity of Korean banks during the period 1980-1994 and describe that technological progress along with the deregulation play an intensive role in improving not only the productivity of individual Korean banks but also the probable yield of Korean banking system as a whole. Hoe et al. (2001) expand the above work by incorporating parametric stochastic cost frontier approach for the time period 1985-1995 with a sample size of 19 Korean banks to investigate the determinants of productive efficiency of Korean banking sector. But they have not noticed any sign of positive affiliation between efficiency of Korean banks and financial liberalization.

\subsection{Ownership and Bank Performance}

The change in ownership structure after financial reform creates new opportunities for the researchers to conduct their valuable studies. Since then a large number of researches have been concentrating on the impact of both foreign and domestic private ownership on bank performance. Thierno et al. (2005) investigate the impact of changing ownership structure on DEA grounded bank efficiency by accumulating the data of 80 commercial banks from Hong Kong, Indonesia, South Korea, Malaysia, the Philippines, and Thailand during the post Asian crisis period 1999-2004. They report that banks with minority domestic private ownership and foreign ownership perform better than state-owned banks and banks with concentrated ownership. The finding of Alejandro et al. (2004) is interesting in the sense that the effect of ownership on bank performance depends primarily on the nature of the country itself. They notice a positive relationship between ownership and bank performance in developing countries and no relationship in developed or industrialized countries while conducting a research during the period 1995-2002 with a sample of 50,000 banks out of which 70 percent are from developed countries and the rest are from developing countries (p. 7). Demirguc-Kunt and Huizinga (2000) also make almost identical statement by acknowledging that in developing countries foreign banks lead the banking sector by obtaining higher spread and profits, whereas the case is exact opposite in developed countries.

Few other researches concentrating on a particular country concur with the above findings. More specifically, Gilbert and Wilson (1998) and Hao et al. (2001) report a positive association between foreign ownership and bank efficiency and a negative association between bank efficiency and state ownership in Korea; Sathye (2001) and Avkiran (1997) notice superior performance of domestic commercial banks compared to their foreign counterparts in Australia during the period 1996 and 1986-1995 respectively; De Young and Nolle (1996) find that income efficiency of foreign commercial banks in the US is lower than domestic US banks during the period 1985 to 1990; and Clarke et al. (2000) investigate the effect of foreign bank entry in Argentina during 1995-1997 and point out that foreign banks are more capable of generating income compared to domestic banks.

\subsection{The Scenario of Bangladesh}

Although Bangladesh adopted financial reform policy and accordingly observed many changes in the financial sector, predominantly in the banking sector, but the number of researches conducted so far is limited except Kabir (2001) who in fact investigates the impact of financial liberalization on economic sector efficiency. He judges the efficiency of financial intermediation in respect of spread between borrowing and lending rates and ratio of reserve money to GDP and outlines that financial and monetary instruments are not contributing fully to efficiency due to lack of proper structural and legal support and policy enforcement. However, judging the efficiency of intermediation on the basis of only spread and reserve money is not adequate at any circumstances as majority of the intermediation in Bangladesh is done by banks. Besides, most of the researches focus on traditional ratio analysis and simple banking indicators to investigate the performance of commercial banks. Chowdhury and Ahmed (2009) measure the performance of 5 private commercial banks from the period 2002-2006 in terms of number of employees and branches, amount of deposits accumulated and loans disbursed, income after tax, and earnings per share. They observe steady growth in these five banks during the sample period. The main limitation of this study is that the sample size is too small and it does not reflect the true picture of the entire banking sector. The research of Hoque et al. (2001) incorporates overall category wise data of different types of banks for assessing bank performance. Their study employs both cross sectional analysis and time series analysis with a sample period of 1988-1998 and uses different traditional ratios. The present study uses individual bank data rather than focusing on overall category wise data to generate clearer picture of bank performance after financial reform and to identify the ownership effect on bank performance. 


\section{Overview of the Banking Sector of Bangladesh}

Bangladesh adopted state directed credit policy with a view to rehabilitating the economy immediately after the independence in 1971. Domestic private commercial banks were not allowed to operate until 1982 and the banking sector was predominantly dictated by government owned commercial and specialized banks (SPBs). Both the deposit and lending rates were fixed by the central bank, and state-owned banks were operating within a protective environment. But, during early 1980s performance of state-owned banks was deteriorated and resource allocation became inefficient. Debnath (2004) argues that the quality of services provided by state-owned banks and SPBs was deteriorated because of the existence of monopoly. This led to the formation of internal and external criticisms on the opening up of the banking sector. Accordingly, the government had to accept financial reform program during 1980s, which was accelerated during 1990s. It was started with privatization and denationalization in 1982-1983 followed by the introduction of Financial Sector Reform Program (FSRP) during 1989-1990 in order to deregulate the banking sector as per the recommendations given by the National Commission on Money, Banking, and Credit and World Bank. As a result, private commercial banks that were highly regulated and limited in numbers become widely available, interest rate is no more determined by the government rather market forces are in the driving seat to direct the interest rate, fixed and pegging systems for the estimation of exchange rate are replaced by the flexible exchange rate system, the heritage of state-directed credit policy comes to an end, number of foreign banks within the boundary of the country is in an increasing trend, various international standards have been adopted for strengthening the functioning of the banking system, and so on. Table 1 indicates significant events of the financial reforms in Bangladesh chronologically started from the year 1982.

The present structure of the financial system in Bangladesh comprises of various types of banks, insurance companies, and non-bank financial institutions. Bangladesh Bank is at the top of the banking system and is accountable for assuring prudential administration and central banking activities for all types of banks operating within the banking industry. On the other hand, Securities and Exchange Commission (SEC) of Bangladesh is the regulatory body for stock market relating activities. According to the Bangladesh Bank Annual Report (2008-2009), the banking system of Bangladesh consists of 4 nationalized commercial banks (NCBs), 5 government owned SPBs, 30 domestic private commercial banks (PCBs) including 7 Islamic banks and 2 denationalized banks, and 9 foreign commercial banks (FCBs). The share of government owned banks in total banking assets, deposits, and credits are 37.82 percent, 35.00 percent, and 32.04 percent respectively. On the other hand, PCBs hold 54.16 percent of the total banking assets, out of which non-Islamic banks, Islamic banks, and denationalized banks capture 36.16 percent, 14.00 percent, and 4.00 percent respectively. All nine FCBs hold 8.36 percent, 7.09 percent, and 8.02 percent of the entire banking deposits, credits, and assets. The PCBs retain the majority of the total deposits and loans, which are 56.64 percent and 60.87 percent.

\section{Data and Methodology}

The present study is based on secondary data. Data are collected from the annual reports of respective banks. It covers a period of eight years from 2001-2008 and the sample period starts from 2001 due to the fact that the current study wants to conduct the analysis just before the ending of the significant financial reform which is exchange rate liberalization in 2003 in Bangladesh. The sample size for measuring bank performance consists of 38 commercial banks including 4 NCBs, 30 domestic PCBs, and 4 FCBs. Out of 30 domestic PCBs 2 are denationalized banks, 7 are Islamic banks, and 21 are non-Islamic PCBs.

In spite of having many limitations, financial ratios were commonly used as non-frontier based measures for measuring the performance of banks for a long period of time. One of the significant limitations of financial ratio is its dependence on yardstick, which can be subjective and ambiguous (Yeh, 1996). In recent years, frontier based methods have been applied for measuring bank performance where firms with high performance are separated from firms with low performance either by using parametric or nonparametric frontier tests (Sathye, 2003). Stochastic frontier approach, the free disposal hull, thick frontier, and Distribution Free Approach are considered as parametric approach; whereas nonparametric approach includes DEA (Molyneux et al., 1996; cited in Sathye, 2003).

Both non-frontier based measures and frontier based measures are used for estimating the performance of sample commercial banks in this study. Return on assets and non-performing loan to total loans are the two traditional non-frontier based measures, while cost efficiency and income efficiency are used as frontier based measures. Cost efficiency and income efficiency are measured by using nonparametric DEA. The selection of performance measures is done in accordance with the statement made by Sathye (2003), where he states that it is always desirable to compare the results generated by DEA with non-frontier measures. Bauer et al. (1998) urge for a measurement of correlation between frontier-based efficiency scores with the traditional non-frontier based performance measures as well to conclude whether frontier-based efficiency scores are useful or not.

DEA was initially developed by Charnes et al. (1978) as a linear programming algorithm with the intention of examining the efficiency of non-profit organizations in the public sector (Sathye, 2001, p. 617). Simply, efficiency means the ability of a firm in transforming its inputs into outputs in the best possible manner. Neal 
(2004) states that Charnes et al. (1978) is in fact uses the efficiency concept developed by Farrell (1957), who actually categorizes efficiency into two major components: technical efficiency which can be regarded as an output oriented approach if focus is on obtaining maximum output from a given level of inputs or an input oriented approach if focus is on minimizing the quantity of inputs for a given level of outputs, and allocative efficiency means the optimal use of inputs in respect of given input prices (p. 175). Afterwards, many researchers have used DEA for other sectors. However, Sherman and Gold (1985) first applied DEA for measuring the performance of the banking sector (Molyneux et al., 1996; cited in Sathye, 2001, p. 617). Later on, Yue (1992), Favero and Papi (1995), Leightner and Lovell (1998), Gilbert and Wilson (1998), Worthington (2000), Sathye (2001), Sathye (2003), Isik and Hasan (2003), Ali et al. (2004), Strum and Williams (2004), Neal (2004), Wu (2005), Ali and Hang (2006), and many others have used DEA for measuring the efficiency of the financial firms.

Each sample is considered as a decision making unit (DMU) in DEA and the efficiency score is calculated for each and every DMU within the sample. DMUs can be either banks or number of branches of banks, depending upon the specification by the researcher. For the current study each bank in the sample is considered as a DMU. In DEA the most efficient firms lie on the frontier and envelope other low performing firms and as such it is treated as a benchmarking tool and provided relative efficiency score of respective firm instead of generating any form of absolute measure (Neal, 2004, p. 176). It is also regarded as an efficient frontier technique and generally computes "the inefficiency in a particular DMU by comparing it to similar DMUs regarded as efficient, rather than trying to associate a DMU's performance with statistical averages that may not be applicable to that DMU" (Avkiran, 2006, p. 276). It means that DEA compares the performance of a firm with the performance of other firms producing similar good or service and having similar size, instead of focusing on a predetermined benchmark of a performance measurement (Worthington, 2000). The efficiency score generated by DEA varies from 0 to 1 . If a DMU holds an efficiency score of 1 , it will be treated as the best practice firm. An efficiency score of 0.90 for a DMU means that the firm is 90 percent efficient compared to the best practice firms. In other words, the firm is 10 percent less efficient compared to the firms lying on the efficient frontier.

\subsection{Reasons for Using DEA}

The present study chooses non-parametric DEA as a tool for measuring income and cost efficiency for two main reasons. First, no previous research in Bangladesh has adopted such kind of analysis for evaluating the performance of commercial banks after the financial reform. Second, according to Bhattacharyya et al. (1997), there is every possibility that restrictive atmosphere and market imperfections distort the prices of inputs and outputs to a great extent in developing countries that makes the application of parametric techniques for computing cost and revenue efficiency more complicated (p. 335). Furthermore, parametric techniques require prior estimation of the functional form and availability of large data for determining income and cost efficiency, which is not always possible in the context of a developing country like Bangladesh.

\subsection{Selection of Inputs and Outputs}

Efficiency measurement by DEA always requires the specification of inputs and outputs. Sathye (2001) observes that the selection of inputs and outputs is crucial as the outcome obtained from DEA is very much responsive to the specification of inputs and outputs. The specification can be done either through using production approach or through intermediation approach, and the banking literature has been dominated by these two approaches (Neal, 2004). This study employs intermediation approach for the specification of inputs and outputs since many researchers like Avkiran (2006), Casu and Molineux (1999), and Colwell and Davis (1992) treat it as superior to production approach.

This study uses three inputs and two outputs for measuring cost efficiency. Loanable funds, physical capital, and labor are the inputs used in this study. On the other hand, investment and loans and advances are considered as the two outputs. Loanable funds is the total of deposits and borrowing, labor means the number of employees working in a DMU at the end of each year, and physical capital is represented by the amount of fixed assets. The price of loanable funds is calculated by dividing the interest expenses by the total amount of loanable funds, the price of physical capital is appeared by dividing the amount of non-interest expenses excluding personnel cost by the amount of physical capital, and the price of labor is computed by dividing the amount of personnel cost by the number of employees. Table 2 gives a snap shot of the specification.

The above specification is done in accordance with the works of Sathye (2001) and Worthington (2000) with few exceptions. This study does not undertake entirely similar approach of Sathye (2001) mainly because of the fact that assumption of demand deposit as output and ignorance of investment from the list of output are not at all justifiable whenever the researcher goes for intermediation approach. Worthington (2000) also uses similar approach adopted by the above author except output specification. He uses personal loan and consumer credit, property and real estate loans, commercial loans, deposit with other deposit taking institutions, and financial securities as outputs. The output specification for this study cannot incorporate this since segregated data for different types of loans and advances are not available for all 38 sample banks used in this study. 
Income efficiency, which identifies the proficiency of a bank in converting its costs into revenues, is measured in this study by using interest expenses and non-interest expenses as inputs and net interest income and non-interest income as outputs. Researchers like Avkiran (1999), Sathye (2003), Sturm and Williams (2004), and Galagedera and Edirisuriya (2005) use exactly similar specification for their respective studies.

\subsection{Model for Identification of Ownership Effect on Bank Performance}

In order to measure the impact of ownership on bank performance, ordinary least square regression with SPSS statistical package is used. The following models are applied for conducting regression analyses where four performance measures selected by the present study are the dependent variables in each case. To be specific, income efficiency (IE), cost efficiency (CE), non-performing loans to total loans and advances (NPL), and return on assets (ROA) for all banks are the dependent variables in the four separate regressions. Both foreign ownership and private ownership are considered as independent variables. In addition, many aspects of banking activities such as nature of business (whether non-Islamic/conventional or Islamic), size, age, unutilized funds, and diversification are integrated as independent variables.

$$
I E / C E / N P L / R O A=\beta_{0}+\beta_{1} D F+\beta_{2} S P+\beta_{3} C I+\beta_{4} D I V+\beta_{5} G A P+\beta_{6} S I Z E+\beta_{7} A G E+\varepsilon_{0}
$$

where DF $(0=$ domestic banks and $1=$ foreign banks $), \mathrm{SP}(0=$ state-owned banks and $1=$ private banks $)$, and CI $(0=$ conventional banks and $1=$ Islamic banks) are dummy variables; DIV stands for diversification, which is calculated by dividing the amount of non-interest income by the value of total revenue; GAP represents unutilized funds (calculated by deducting the sum of loans and investments from the total of deposits and borrowings) relative to total loanable funds available; SIZE represents the asset size of a bank relative to the total banking assets; and AGE indicates the number of years in operations.

\section{Empirical Results}

Table 3 represents the summary statistics of sample banks during the period under study. Altogether, the sample banks capture 93 percent of total banking assets, 95 percent of total banking deposits, and 92 percent of total banking credits in 2008 compared to 84 percent, 90 percent, and 85 percent respectively in 2001.

The figures 1 and 2 indicate the performance of sample banks measured in terms of income efficiency, cost efficiency, NPL, and ROA. The income efficiency scores are obtained by using Slacks-Based Measure Model (SBM) of DEA under constant returns to scale (CRS) assumption and the cost efficiency scores are derived by using Cost Efficiency Model under CRS assumption depending upon the specified inputs and outputs in both cases. The software developed by Cooper et al. (2006) is used for computing both income and cost efficiency. The income efficiency and cost efficiency of all sample banks have been increased by 37.84 percent and 15.28 percent respectively in 2008 compared to 2001. The NPL stood at 16.05 percent in 2001, which is reduced to 5.76 percent in 2008. On the other hand, ROA also reflects an enhancement as it is 1.67 percent in 2008 compared to 1.10 percent in 2001. Both traditional measures and frontier based measures indicate an evidence of improvement in bank performance during the sample period in Bangladesh. The advancement can be attributed to the changes in the banking sector assured by the financial reform policy.

Table 4 gives the descriptive statistics of dependent and independent variables used for measuring the ownership effect on bank performance. The maximum and minimum income efficiency scores are 1 and 0.06 , while cost efficiency scores are 1 and 0.54 . The highest score belongs to the most efficient bank and the lowest score represents the least efficient bank. On average 27.4 percent of total revenue of sample banks is represented by non-interest income, while 10.3 percent of total loanable funds remain unutilized. The average age of the sample banks is 15.84 and still one of the NCBs holds 16.6 percent of the total banking assets.

The outcomes of the regression models are given in the tables 5,6,7, and 8 . All the four regression models are statistically significant at 1 percent level (represented by F-test), which indicate that all independent variables as a package have a relationship with each and every performance measure. According to the findings, foreign ownership has a statistically significant positive impact on bank performance. On the other hand, private ownership has a statistically significant positive impact on income efficiency and return on assets, whereas negative effect on cost efficiency. Regarding NPL, both foreign and private ownership have a negative impact. It means that a bank with either foreign or private ownership tends to have a lower amount of NPL relative to total loanable funds.

The nature of business (whether Islamic or conventional) does not have any statistically significant impact on bank performance. Such finding can be elucidated by the fact that there is no significant difference among sample Islamic banks and non-Islamic domestic PCBs regarding the input prices used in this study, interest rate spread, expenditure income ratio, and so on. However, this subject matter still requires some further research since Islamic banking is rising in Bangladesh,

Diversification becomes very common after financial reform and banks nowadays participate in other activities such as off balance sheet activities, security financing, factoring, etc. in addition to conventional borrowing and lending. But, according to the findings, these diversification activities do not have any statistically significant 
impact on income; rather adversely affect both cost efficiency and NPL. It gives an indication that banks are using their resources for non-core banking activities, which is hindering their performance. Ali and Hang (2006) also mention that "an increase in investments substitutes banks' resources away from higher-earning, albeit riskier, loans and advances" (p. 661). Likewise, unutilized fund is another concerning element for banks since it does not add any value in income generation instead it inversely affects cost efficiency of banks.

Banks are expected to gain knowledge with age. But there is no clear evidence in Bangladesh in this regard since age does not have any significant impact on income. In contrast, banks with higher age are less cost efficient with high NPL. Hao et al. (2001) also do not get any sign of improvement in bank performance governed by age in Korea. On the other hand, size of the bank does not have any impact on bank performance. Similar finding is also reported by Yildirim (2002).

\section{Conclusion}

This study focuses on bank performance after the financial reform in Bangladesh and four performance measures are used for assessing bank performance out of which two are DEA grounded frontier based measures. NPL and ROA are the traditional non-frontier measures and used mainly to compare the results generated by DEA grounded income and cost efficiency. All the four performance indicators reflect an improvement of bank performance. Institutional changes assured by the financial reform policy of Bangladesh Bank not only induce individual banks to improve their performance but also bring discipline and prudential attitude within the banking industry as a whole. It is also evident from the finding that a bank with either foreign or private ownership is income efficient. On the other hand, a bank with private ownership, longer period of operations, excessive diversification activities, and higher amount of unutilized funds tends to become less cost efficient and non-performing loan increases with the rise of diversification activities and periods of operation and decreases with foreign or private ownership. Therefore, encouraging foreign and domestic private ownership can be a suitable strategy for accelerating the performance of commercial banks in Bangladesh. At the same time, the central bank has to monitor diversification activities and unutilized funds of commercial banks as they do not have any positive impact on bank performance. It can be argued that too much emphasis on security investment and other diversification activities urges banks to replace financial and non financial resources from core banking activities to non-core activities. Even, there is every possibility that any financial turmoil in the security market can expose banks to an obvious disaster.

This study can be extended in two different ways. Firstly, an analysis can be done for comparing the performance of commercial banks before and after the implementation of financial reform in Bangladesh by using similar methodology with an extensive sample period. Secondly, further research can be conducted by adopting parametric test to measure performance in absolute form in addition to non-parametric DEA subject to successful formation of prior functional form.

\section{References}

Alejandro, M., Ugo, P., \& Monica, Y. (2004). Bank Ownership and Performance. Working Paper 518, Research Department, Inter-American Development Bank, November, 2004. [Online] Available: http://www.iadb.org/res/publications/pubfiles/pubWP-518.pdf on May 24, 2010.

Ali, A., \& Hang, L. (2006). Economic Reforms and Bank Efficiency in Developing Countries: The Case of the Indian Banking Industry. Applied Financial Economics, 16, 653-663.

Ali, A., Tony, C., \& Hang, L. (2004). Financial Liberalization and Bank Efficiency: A Comparative Analysis of India and Pakistan. Applied Economics, 36, 1915-1924.

Avkiran, N. K. (1997). Performance of Foreign Banks in Australia. The Australian Banker. The Australian Institute of Banking and Finance, 222-224.

Avkiran, N. K. (1999). The Evidence of Efficiency Gains: The Role of Mergers and the Benefits to the Public. Journal of Banking and Finance, 23, 991-1013.

Avkiran, N. K. (2000). Rising Productivity of Australian Trading Banks under Deregulation 1986-1995. Journal of Economics and Finance, 24, 122-140.

Avkiran, N. K. (2006). Developing Foreign Bank Efficiency Models for DEA Grounded in Finance Theory. Socio-Economic Planning Sciences, 40, 275-296.

Bangladesh Bank. (2009). Annual Report 2008-2009. Bangladesh Bank, Dhaka, Bangladesh.

Bauer, P. W., Berger, A. N., \& Humphrey, D. B. (1993). Efficiency and Productivity Growth in US Banking, in The Measurement of Productive Efficiency: Techniques and Applications (Eds) H. O. Fried, C. A. K. Lovell, and S. S. Schmidt, Oxford University Press, UK, 386-414.

Bauer, P. W., Berger, A. N., Ferrier, G. D., \& Humphrey, D. B. (1998). Consistency Conditions for Regulator Analysis of Financial Institutions: A Comparison of Frontier Efficiency Methods. Journal of Economics and Business, 50, 85-114. 
Beck, T., \& Rahman, M. H. (2006). Creating a More Efficient Financial System: Challenges for Bangladesh. World Bank Policy Research Working Paper 3938, June 2006.

Benerjee, A., \& Singh, S. K. (2001). Banking and Financial Sector Reforms in India. Deep and Deep Publications Pvt. Ltd., India.

Berg, S., Forsund, F., \& Jansen, E. (1992). Malmquist Indices of Productivity Growth during the Deregulation of Norwegian Banking 1980-1989. Scandinavian Journal of Economics, 94 (suppl.), 211-228.

Berger, A. N., \& Mester, L. J. (2001). Explaining the Dramatic Changes in Performance of US Banks: Technological Change, Deregulation, and Dynamic Change in Competition. Working Paper No. 01-6, University of Pennsylvania.

Berger, A. N., DeYoung, R., Genay, H., \& Udell, G. (2000). Globalization of Financial Institutions: Evidence from Cross-Border Banking Performance. Brookings-Wharton Papers on Financial Services, 3, 23-120.

Berger, A.N., \& Humphrey, D.B. (1997). Efficiency of Financial Institutions: International Survey and Directions for Future Research. European Journal of Operational Research, 98, 175-212.

Bhattacharya, A., Lovell, C. A. K., \& Sahay, P. (1997). The Impact of Liberalization on the Productive Efficiency of Indian Commercial Banks. European Journal of Operations Research, 98, 332-345.

Canhoto, A., \& Dermine, J. (2003). A Note on Banking Efficiency in Portugal: New vs. Old Banks. Journal of Banking and Finance, 27, 2087-2098.

Casu, B., \& Molyneux, P. (1999). A Comparative Study of Efficiency in European Banking. Working Paper, School of Accounting, Banking and Economics, University of Wales, UK.

Chaffai, M. E. (1997). Productivity and Efficiency Performance of the Tunisian Banking Industry Before and After the Economic Liberalization Program: An Economic Study Using Panel Data, in Models of Economic Policy Evaluation Theory and Practice: An International Experience, Research, in Human Capital, and Development, Vol. 11 (Eds) R. Dahel and I. Sirageldin, JAI Press, Greenwich, 335-350.

Charnes, A., Cooper, W. W., \& Rhodes, E. (1978). Measuring Efficiency of Decision Making Units. European Journal of Operations Research, 2, 429-444.

Chen, Y. (2001). An Estimation of X-inefficiency in Taiwan's Banks. Applied Financial Economics, 11, 237-242.

Chowdhury, T. A., \& Ahmed, K. (2009). Performance Evaluation of Selected Private Commercial Banks in Bangladesh. International Journal of Business and Management, 4(4), 86-97.

Clarke, G., Cull, R., D’Amato, L., \& Molinari, A. (2000). The Effect of Foreign Entry on Argentina's Domestic Banking Sector. In: S. Claessens and M. Jansen, editors. Internationalization of Financial Services: Issues and Lessons for Developing Countries. Boston, United States: Kluwer Academic.

Claudia, G., Philip, M., \& Edward, P. M. G. (2004). Analyzing the Determinants of Bank Efficiency: the Case of Italians Banks. Applied Economics, 36, 215-227.

Colwell, R. J., \& Davis, E. P. (1992). Output and Productivity in Banking. Scandinavian Journal of Economics, 94, 111-129.

Cooper, W. W., Lawrence, M. S., \& Kaoru, T. (2006). Data Envelopment Analysis: A Comprehensive Text with Models, Applications, References, and DEA Solver Software. Boston: Springer.

De Young, R., \& Nolle, D. (1996). Foreign-Owned Banks in the U.S.: Earning Market Share or Buying It? Journal of Money, Credit and Banking, 28, 622-636.

Debnath, R. M. (2004). Banks and Legal Environment. Nabajuga Prokashani, Dhaka, Bangladesh.

Demirguc-Kunt, A., \& Huizinga, H. (2000). Determinants of Commercial Bank Interest Margins and Profitability: Some International Evidence. World Bank Economic Review, 13(2), 379-408.

Farrell, M. J. (1957). The Measurement of Productive Efficiency. Journal of the Royal Statistical Society, A CXX, part 3, 253-290.

Favero, C. A., \& Papi, L. (1995). Technical efficiency and Scale Efficiency in the Italian Banking Sector: a Non-parametric Approach. Applied Economics, 27(4), 385-395.

Galagedera, D. U. A., \& Edirisuriya, P. (2005). Performance of Indian Commercial Banks (1995-2002). South Asian J Manage, 12, 52-74.

Gilbert, R. A., \& Wilson, P. W. (1998). Effects of Deregulation on the Productivity of Korean Banks. Journal of Economics and Business, 46, 39-64.

Hao, J., Hunter, W. C., \& Yang, W. K. (2001). Deregulation and Efficiency: the Case of Private Korean Banks. Journal of Economics and Business, 53, 237-254.

Hoque, H. A. A. B., \& Khan, A. R (2001). Financial Performance of Banks: A Statistical Analysis. Journal of Business Studies, University of Dhaka, 22(1), 27-49. 
Hossain, A., \& Chowdhuey, A. (1996). Monetary and Financial Policies in Developing Countries Growth and Stabilization. Routledge Studies in Development Economics, London and New York.

Humphrey, D., \& Pulley, L. (1997). Banks' Responses to Deregulation: Profits, Technology, and Efficiency. Journal of Money, Credit and Banking, 29, 73-93.

Isik, I., \& Hasan, M. K. (2003). Financial Deregulation and Total Factor Productivity Change: An Empirical Study of Turkish Commercial Banks. Journal and Banking and Finance, 27(8), 1455-1485.

Kabir, S. H. (2001). Is Financial Liberalization a Vehicle for Economic Sector Efficiency of Bangladesh? Bank Parikrama A Journal of Banking \& Finance, Bangladesh Institute of Bank Management, Vol. XXVIII and XXIX, June 2003-December 2004, 147-169.

Leightner, J. E., \& Lovell, C. A. K. (1998). The Impact of Financial Liberalization on the Performance of Thai Banks. Journal of Economics and Business, 50, 115-131.

Maudos, J., \& Pastor, J. M. (2003). Cost and Profit Efficiency in the Spanish Banking Sector (1985-1996): A Nonparametric Approach. Applied Financial Economics, 13, 1-12.

Ministry of Finance. (2008). Bangladesh Economic Review, Ministry of Finance, Govt. of Bangladesh, Dhaka, Bangladesh.

Molyneux, P., Altunbas, Y., \& Gardener, E. (1996). Efficiency in European Banking. John Wiley Chichester, 198.

Neal, P. (2004). X-Efficiency and Productivity Change in Australian Banking. Australian Economic Papers, 43(2), 174-191.

Sathye, M. (2001). X-Efficiency in Australian Banking: An Empirical Investigation. Journal of Finance and Banking, 25, 613-630.

Sathye, M. (2003). Efficiency of Banks in a Developing Economy: the Case of India. European Journal of Operations Research, 148(3), 662-671.

Sherman, D., \& Gold, F. (1985). Branch Operating Efficiency: Evaluation with Data Envelopment Analysis. Journal of Banking and Finance, 9, 297-315.

Shyu, J. (1998). Deregulation and Bank Operating Efficiency: An Empirical Study of Taiwan's Banks. Journal of Emerging Markets, 3, 27-46.

Strum, J., \& Williams, B. (2004). Foreign Bank Entry, Deregulation, and Bank Efficiency: Lessons from the Australian Experience. Journal of Banking and Finance, 28, 1775-1799.

Thierno, A. B., Santos, J. D., Laetitia, L., \& Amine, T. (2005). Ownership Structure and Bank Efficiency in the Asia Pacific Region. Paper prepared for the European Commission Asia-Link project B7-3010/2005/105-139: Safety and Soundness of the Financial System coordinated by the University of Limoges.

Worthington, A. C. (2000). Cost Efficiency in Australian Non-Bank Financial Institutions: A Non-Parametric Approach. Journal of Accounting and Finance, 40 (1), 75-97.

$\mathrm{Wu}$, S. (2005). Productivity and Efficiency Analysis of Australian Banking Sector under Deregulation. In Proceedings of the Australian Conference of Economists 2005, Melbourne: University of Melbourne/Conference Maker.

[Online]

Available: http://editorialexpress.com/cgi-bin/conference/download.cgi?db_name=ACE2005\&paper_id=192 on May 04, 2010.

Yeh, Q. (1996). The Application of Data Envelopment Analysis in Conjunction with Financial Ratios for Bank Performance Evaluation. Journal of Operational Research Society, 47, 980-988.

Yildirim, C. (2002). Evolution of Banking Efficiency within an Unstable Macroeconomic Environment: The Case of Turkish Commercial Banks. Applied Economics, 34, 2289-2301.

Yue, P. (1992). Data Envelopment Analysis and Commercial Bank Performance with Applications to Missourie Banks. Federal Reserve Bank of St Louis Economic Review, January/February, 31-45.

\section{Notes}

Note 1. The word 'financial reform' has been used interchangeably with the terms financial deregulation and financial liberalization (Banerjee and Singh, 2001).

Note 2. BDT stands for Bangladesh Taka; Taka is the currency of Bangladesh.

Note 3. The formula used for transformation is, $\delta=\frac{d-d^{\min }}{d^{\max }-d^{\min }}$. This formula is applied because of the availability of the maximum and minimum values for all the series of data that are needed to be normalized. Whenever, $\mathrm{d}=\mathrm{d}^{\min }$, the value of $\delta$ becomes zero. On the other hand, if $\mathrm{d}=\mathrm{d}^{\max }$, then $\delta=1$. 
Table 1. Significant Financial Reform Events

\begin{tabular}{|l|l|}
\hline Year & \multicolumn{1}{|c|}{ Event } \\
\hline 1982 & Promotion of private ownership of commercial banks. \\
\hline 1983 & $\begin{array}{l}\text { Denationalization of two government owned commercial banks. } \\
\text { Introduction of the concept of Islamic banking. }\end{array}$ \\
\hline 1989 & Adoption of FSRP. \\
\hline 1990 & $\begin{array}{l}\text { Imposition of bands for lending rates and ceiling for savings and time deposit rates. } \\
\text { Promulgation of Money Loan Court Act-1990. }\end{array}$ \\
\hline 1991 & $\begin{array}{l}\text { Fixation of Cash Reserve Requirement (CRR) and Statutory Liquidity Reserve (SLR) as 10 } \\
\text { percent and 20 percent respectively. }\end{array}$ \\
\hline 1992 & $\begin{array}{l}\text { Removal of lending rate bands except for three sectors: agriculture, small and medium } \\
\text { enterprises (SMEs), and export; and ceiling for savings and fixed deposits. } \\
\text { Establishment of Credit Information Bureau (CIB). }\end{array}$ \\
\hline 1993 & $\begin{array}{l}\text { Financial Institutions Act-1993. } \\
\text { Formation of SEC. }\end{array}$ \\
\hline 1996 & $\begin{array}{l}\text { Implementation of Basel I. } \\
\text { Application of revised CAMELS rating system. }\end{array}$ \\
\hline 1997 & $\begin{array}{l}\text { Elimination of floor rates of deposits. } \\
\text { Bankruptcy Act-1997. }\end{array}$ \\
\hline 1998 & Revision of loan classification and provisioning policy. \\
\hline 1999 & $\begin{array}{l}\text { Withdrawal of lending rate bands for agriculture and SMEs. } \\
\text { Revision of loan classification and provisioning. }\end{array}$ \\
\hline 2000 & Bank Deposit Insurance Act 2000. \\
\hline 2001 & Further amendment of loan classification and provisioning. \\
\hline 2003 & $\begin{array}{l}\text { Launching of flexible exchange rate. } \\
\text { Money Laundering Prevention Act-2002 became effective. } \\
\text { Enaction of Money Loan Court Act-2003. }\end{array}$ \\
\hline 2005 & Introduction of Early Warning System (EWS). \\
\hline 2006 & The rates of CRR and SLR became 5 percent and 18 percent respectively. \\
\hline & Formal initiation of Basel II. \\
\hline
\end{tabular}
Source: Compiled by the Authors

Table 2. Summary of Inputs and Outputs for Measuring Cost Efficiency

\begin{tabular}{|c|c|}
\hline Inputs & Input Prices \\
\hline $\begin{array}{l}\text { 1. Loanable Funds (deposits + borrowings) } \\
\text { 2. Physical Capital (amount of fixed assets) } \\
\text { 3. Labor (number of employees) }\end{array}$ & $\begin{array}{l}\text { Interest expenses divided by total loanable funds. } \\
\text { Non-interest expenses excluding personnel cost divided } \\
\text { by fixed assets. } \\
\text { Personnel cost divided by number of employees. }\end{array}$ \\
\hline \multicolumn{2}{|l|}{ Outputs } \\
\hline $\begin{array}{l}\text { 1. Loans and advances } \\
\text { 2. Investments }\end{array}$ & \\
\hline
\end{tabular}

Table 3. Summary Statistics of Sample Banks (Amount in BDT (Note 2) million except number of employees)

\begin{tabular}{|l|r|r|r|r|r|}
\hline & \multicolumn{1}{|c|}{ N } & \multicolumn{1}{c|}{ Minimum } & \multicolumn{1}{c|}{ Maximum } & \multicolumn{1}{c|}{ Mean } & \multicolumn{1}{c|}{ Std. Deviation } \\
\hline Deposit & 8 & $884,823.55$ & $2,466,608.93$ & $1,508,806.12$ & $554,867.92$ \\
Borrowing & 8 & $30,983.03$ & $56,744.58$ & $39,844.71$ & $10,753.92$ \\
Credit & 8 & $655,998.02$ & $1,959,551.62$ & $1,173,933.97$ & $457,292.70$ \\
Fixed Assets & 8 & $8,599.48$ & $48,540.38$ & $21,275.79$ & $14,848.67$ \\
Investment & 8 & $130,594.31$ & $421,687.99$ & $248,033.20$ & $97,719.22$ \\
Interest Income & 8 & $60,975.19$ & $219,056.55$ & $116,605.62$ & $56,785.62$ \\
Interest Expenses & 8 & $50,880.79$ & $150,646.68$ & $85,490.98$ & $35,845.86$ \\
Net Interest Income & 8 & $10,094.40$ & $68,409.87$ & $31,114.64$ & $20,939.76$ \\
Non Interest Income & 8 & $26,123.27$ & $87,416.73$ & $48,536.90$ & $21,131.08$ \\
Non Interest Expense & 8 & $18,988.90$ & $65,135.25$ & $36,831.12$ & $15,458.14$ \\
Salaries and Allowances & 8 & $12,068.25$ & $37,523.91$ & $21,396.54$ & $8,930.72$ \\
Number of Employees & 8 & 91,453 & 108,371 & 97,198 & 6,170 \\
\hline
\end{tabular}


Table 4. Descriptive Statistics of Regression Variables

\begin{tabular}{|l|r|r|r|r|r|}
\hline Variables & $\mathrm{N}$ & Minimum & Maximum & \multicolumn{1}{c|}{ Mean } & Std. Deviation \\
\hline Cost Efficiency & 38 & 0.540 & 1.000 & 0.793 & 0.101 \\
Income Efficiency & 38 & 0.060 & 1.000 & 0.449 & 0.200 \\
NPL & 38 & 0.420 & 32.130 & 7.919 & 8.543 \\
ROA & 38 & -2.370 & 6.860 & 1.865 & 1.941 \\
DF & 38 & 0.000 & 1.000 & 0.105 & 0.311 \\
SP & 38 & 0.000 & 1.000 & 0.895 & 0.311 \\
CI & 38 & 0.000 & 1.000 & 0.184 & 0.393 \\
DIV & 38 & 0.140 & 0.460 & 0.274 & 0.078 \\
GAP & 38 & -0.080 & 0.340 & 0.103 & 0.089 \\
SIZE & 38 & 0.003 & 0.166 & 0.023 & 0.031 \\
AGE & 38 & 5.500 & 32.500 & 15.842 & 9.451 \\
\hline
\end{tabular}

Table 5. Income Efficiency and Ownership

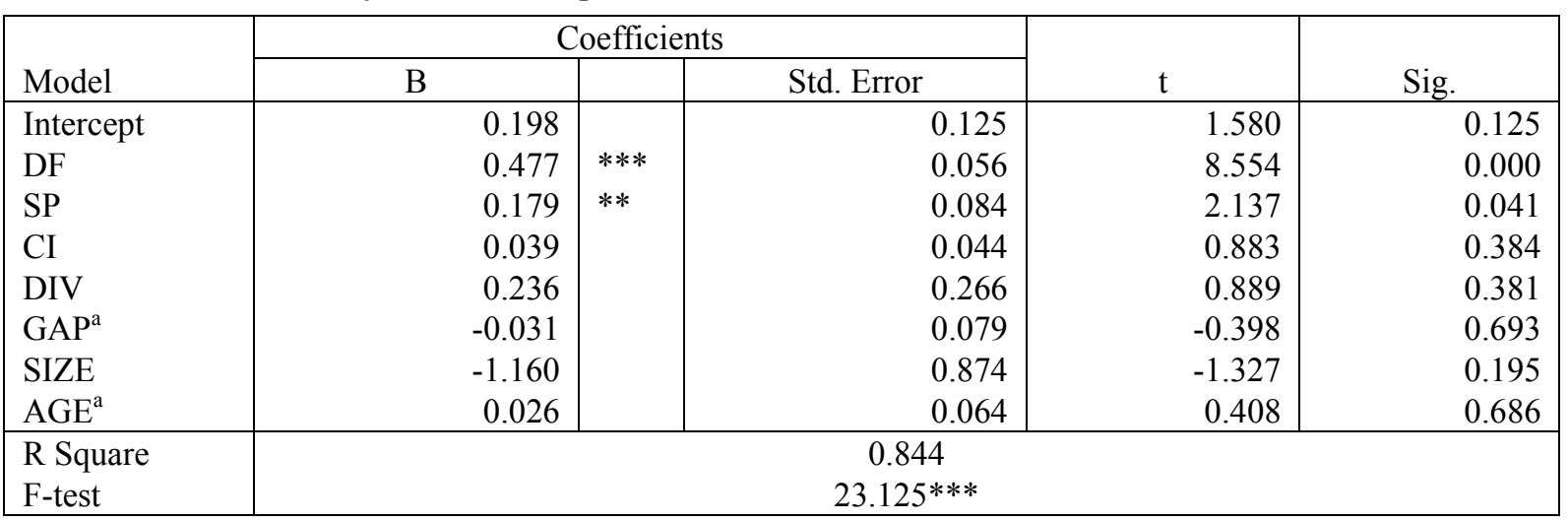

Table 6. Cost Efficiency and Ownership

\begin{tabular}{|c|c|c|c|c|c|}
\hline \multirow[b]{2}{*}{ Model } & \multicolumn{3}{|c|}{ Coefficients } & \multirow[b]{2}{*}{$\mathrm{t}$} & \multirow[b]{2}{*}{ Sig. } \\
\hline & $\mathrm{B}$ & & Std. Error & & \\
\hline Intercept & 1.171 & $* * *$ & 0.090 & 13.000 & 0.000 \\
\hline DF & 0.217 & $* * *$ & 0.040 & 5.416 & 0.000 \\
\hline SP & -0.101 & $*$ & 0.060 & -1.675 & 0.100 \\
\hline CI & 0.017 & & 0.032 & 0.529 & 0.601 \\
\hline DIV & -0.393 & $* *$ & 0.191 & -2.059 & 0.048 \\
\hline $\mathrm{GAP}^{\mathrm{a}}$ & -0.369 & $* * *$ & 0.057 & -6.526 & 0.000 \\
\hline SIZE & 0.492 & & 0.627 & 0.785 & 0.439 \\
\hline $\mathrm{AGE}^{\mathrm{a}}$ & -0.152 & $* * *$ & 0.046 & -3.325 & 0.002 \\
\hline R Square & & & 0.683 & & \\
\hline F-test & & & $9.249 * * *$ & & \\
\hline
\end{tabular}

Table 7. NPL and Ownership

\begin{tabular}{|c|c|c|c|c|c|}
\hline \multirow[b]{2}{*}{ Model } & \multicolumn{3}{|c|}{ Coefficients } & \multirow[b]{2}{*}{$\mathrm{t}$} & \multirow[b]{2}{*}{ Sig. } \\
\hline & $\mathrm{B}$ & & Std. Error & & \\
\hline Intercept & 0.108 & & 4.671 & 0.023 & 0.982 \\
\hline DF & -12.179 & $* * *$ & 2.116 & -5.755 & 0.000 \\
\hline SP & -10.235 & $* * *$ & 3.182 & -3.216 & 0.003 \\
\hline $\mathrm{CI}$ & 2.085 & & 1.685 & 1.237 & 0.226 \\
\hline DIV & 40.605 & $* * *$ & 10.127 & 4.009 & 0.000 \\
\hline GAP & 3.185 & & 7.163 & 0.445 & 0.660 \\
\hline SIZE & -8.691 & & 33.175 & -0.262 & 0.795 \\
\hline AGE & 0.420 & $* * *$ & 0.089 & 4.699 & 0.000 \\
\hline $\begin{array}{l}\text { R Square } \\
\text { F-test }\end{array}$ & & & $\begin{array}{c}0.876 \\
30.257^{* * *}\end{array}$ & & \\
\hline
\end{tabular}


Table 8. ROA and Ownership

\begin{tabular}{|c|c|c|c|c|c|}
\hline \multirow[b]{2}{*}{ Model } & \multicolumn{3}{|c|}{ Coefficients } & \multirow[b]{2}{*}{$\mathrm{t}$} & \multirow[b]{2}{*}{ Sig. } \\
\hline & $\mathrm{B}$ & & Std. Error & & \\
\hline Intercept & -1.210 & & 1.068 & -1.132 & 0.266 \\
\hline DF & 4.093 & $* * *$ & 0.484 & 8.457 & 0.000 \\
\hline SP & 3.263 & $* * *$ & 0.728 & 4.483 & 0.000 \\
\hline $\mathrm{CI}$ & -0.499 & & 0.385 & -1.294 & 0.205 \\
\hline DIV & 0.514 & & 2.316 & 0.222 & 0.826 \\
\hline GAP & -2.458 & & 1.638 & -1.500 & 0.144 \\
\hline SIZE & -2.774 & & 7.587 & -0.366 & 0.717 \\
\hline $\mathrm{AGE}$ & -0.001 & & 0.020 & -0.056 & 0.956 \\
\hline $\begin{array}{l}\text { R Square } \\
\text { F-test }\end{array}$ & & & $\begin{array}{c}0.874 \\
29.826 * * *\end{array}$ & & \\
\hline
\end{tabular}

The Symbols $(* * *),(* *)$, and $(*)$ represent statistical significance at $1 \%, 5 \%$, and $10 \%$ respectively. ${ }^{\text {a }}$ These variables are normalized (Note 3 ) for the calculation.

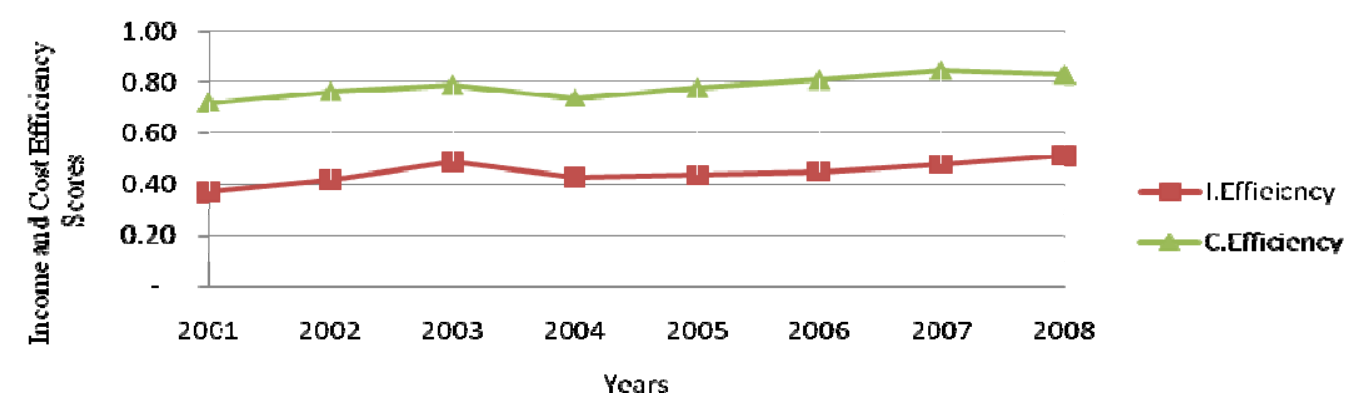

Figure 1. Income and Cost Efficiency of Sample Banks

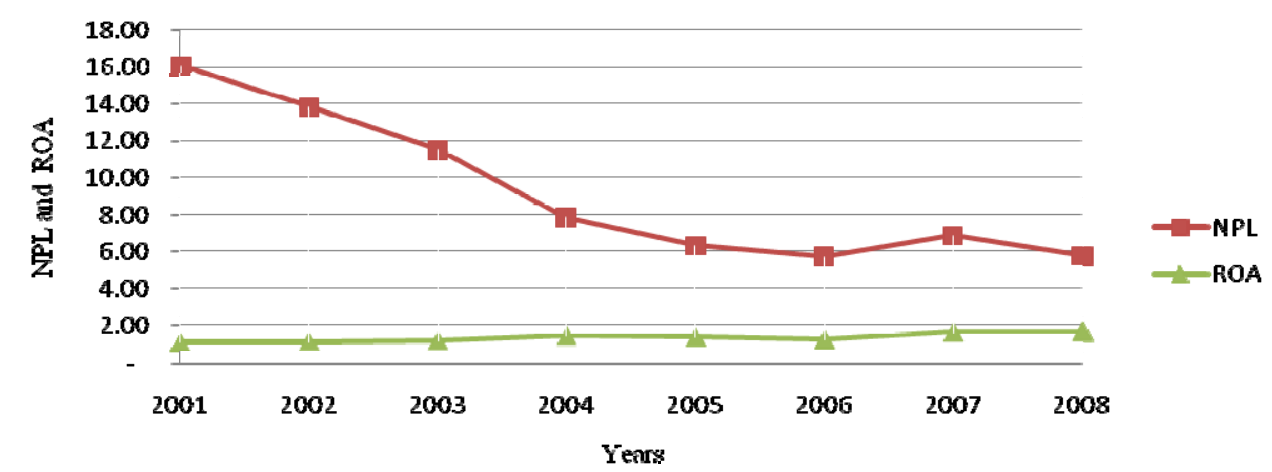

Figure 2. NPL and ROA of Sample Banks 